\title{
Respon Umur Fisiologi Bahan Stek Mawar (Rosa Sp.) pada Pemberian Konsentrasi indole-3- butyric acid (IBA) yang Berbeda
}

\section{Responof the Age Materials of Rose (Rose Sp.) Cuttings on Various Concentrationof indole-3- butyric acid (IBA)}

\author{
Risty Dwi Sylviana ${ }^{1 *}$, Budi Adi Kristanto ${ }^{2}$, Endang Dwi Purbajanti ${ }^{3}$ \\ ${ }^{1}$ Program Studi Agroteknologi, Departemen Pertanian, Fakultas Peternakan dan Pertanian \\ Universitas Diponegoro \\ ${ }^{2}$ Departemen Pertanian, Fakultas Peternakan dan Pertanian, Universitas Diponegoro \\ *Email : ristyslvn@gmail.com
}

Diterima 9 Juni 2019 / Disetujui 26 Agustus 2019

\begin{abstract}
ABSTRAK
Bunga mawar memiliki nilai ekonomi tinggi dan permintaan bunga potong ataupun tanaman hias terus meningkat, maka mawar perlu dikembangkan menjadi produk unggulan agribisnis. Penelitian bertujuan untuk mengetahui bagian batang tanaman yang masih dapat digunakan sebagai bahan stek dan konsentrasi IBA yang mampu memacu pertumbuhan stek batang tanaman mawar. Penelitian menggunakan rancangan acak lengkap faktorial $3 \times 5$. Faktor pertama adalah umur bahan stek yaitu umur bahan stekmuda (10 $\mathrm{cm}$ dari ujung), umurbahanstek sedang (antara 20-40 cm dari ujung) dan umur bahan stek tua (40-50 cm dari ujung). Faktor kedua adalah konsentrasi IBA, yaitu 0, 25, 50, 75, dan 100 ppm. Data yang diperoleh kemudian dianalisis ragam dan dilanjutkan dengan uji Duncan's Multiple Range Test (DMRT). Hasil penelitian dapat disimpulkan bahwa bagian ujung batang atau cabang tanaman berumur muda tidak dapat digunakan sebagai bahan stek. Umur bahan stek sedang diperlukan konsentrasi IBA 50 ppm dan umur bahan stek tua diperlukan konsentrasi 75 ppm untuk dapat mempercepat proses pertumbuhan pasa stek tanaman mawar.
\end{abstract}

Kata kunci : auksin, pertumbuhan, tunas

\section{ABSTRACT}

Roses have high economic value and demand for cut flowers or ornamental plants continues to increase, so roses need to be developed into superior agribusiness products. The aim of this research is to find out which parts of plant stems can still be used as cuttings and IBA concentrations that can stimulate the growth of rose stem cuttings. The study used a $3 \times 5$ factorial complete random design. The first factor is the age of the cuttings, namely the age of the cuttings $(10 \mathrm{~cm}$ from the tip), the average age of the cuttings (between $20-40 \mathrm{~cm}$ from the tip) and the age of the old cuttings (40-50 cm from the tip). The second factor is the concentration of IBA, which is $0,25,50,75$, and $100 \mathrm{ppm}$. The data obtained were then analyzed by variance and continued with Duncan's Multiple Range Test (DMRT). The results of the study concluded that the tip of the stem or branches of young plants cannot be used as cuttings. Age of medium cuttings required IBA concentration of $50 \mathrm{ppm}$ and age of old cuttings required a concentration of $75 \mathrm{ppm}$ to be able to accelerate the growth process of rose plant cuttings.

Keywords: auxin, growth, shoots

\section{PENDAHULUAN}

Mawar merupakan salah satu tanaman hias yang banyak dikenal dapatditemukan di semua negara, sehingga dijuluki sebagai "Ratu Segala Bunga (Queen of Flower)" (Fitriani, 2017). Berdasarkan data Badan Pusat Statistik (BPS) jumlah produksi mawar terus mengalami peningkatan dari tahun 2008 hingga tahun 2010. Tahun 2010 jumlah produksi mawar menduduki peringkat kedua setelah krisan, yaitu 120.485 .784 tangkai. Peningkatan produksi tersebut merupakan dampak dari peningkatan permintaan konsumen terhadap mawar. Bungamawar memiliki nilai jual 
yang tinggi karena keindahan dan aromanya, serta bermanfaat dan memiliki banyak khasiat. Berdasarkan kegunaannya, tanaman mawar sering digunakan sebagai tanaman hias pot, bunga potong serta dapat digunakan sebagai tanaman penghias taman, selain itu mawar juga digunakan sebagai bunga tabur (rampai), bahan industri kosmetik dan bahan industri pewangi (Suradinata dan Wulansari, 2015).

Tanaman mawar dapat tumbuh dari dataran rendah hingga dataran tinggi di daerah tropis. Tanaman mawar yang dibudidayakan di daerah yang beriklim sejuk (dataran tinggi) warna bunganya lebih cerah dengan ukuran bunga yang lebih besar (Mattjik, 2009). Tanaman mawar dapat diperbanyak secara generatif maupun secara vegetatif. Secara vegetatif dengan stek batang atau cabang, cangkok, dan okulasi. Cara stek lebih dipilih, karena stek menghasilkan tanaman yang memiliki persamaan dengan induknya dalam hal umur, tinggi, ketahanan terhadap penyakit dan menghasilkan bibit tanaman dalam jumlah banyak. Batang mawar yang bagus untuk distek adalah batang pada bagian tengahnya, sebab jika mengambil bagian batang yang masih terlalu muda akan sulit ditanam. Stek akan sulit berhasil karena batang muda tidak mampu beradaptasi akibat masih mudanya jaringan tanaman tersebut.

Stek seringkali mengalami kegagalan dengan tidak tumbuhnya akar (Fitriani et al., 2017). Keberhasilan stek dipengaruhi oleh faktor bahan stek, pemberian zat pengatur tumbuh, media tanam, dan kondisi lingkungan selama penyetekan (Adriana et al., 2014). Kondisi fisiologis tanaman yang mempengaruhi penyetekan adalah umur bahan stek, jenis tanaman, adanya tunas dan daun muda pada stek, persediaan bahan makanan, dan zat pengatur tumbuh (Panjaitan et al., 2014).

Hormon tumbuh yang mempunyai pengaruh paling besar pada pertumbuhan akar stek adalah indole-3-butyric acid (IBA). Tujuan pemberian hormon IBA adalah untuk meningkatkan persentase stek yang berakar, mempercepat pembentukan dan pertumbuhan akar, meningkatkan jumlah dan kualitas akar,serta untuk menyeragamkan munculnya akar (Putri dan Danu, 2014), sehingga kualitas dan vigor stek menigkat. Hormon IBA memegang peranan penting pada proses pembelahan dan pembesaran sel, terutama pada awal pembentukan akar (Sari et al., 2014).

Penelitian ini bertujuan untuk mengkaji pengaruh umur bahan stek atau bagian batang dan cabang yang masih dapat digunkan sebagai bahan stek dan konsentrasi IBA terhadap pertumbuhan stek tanaman mawar.

\section{METODE PENELITIAN}

Alat yang digunakan dalam penelitian ini mencakup polybag ukuran $20 \times 15 \mathrm{~cm}$, sekam bakar, pupuk kandang sapi dan tanah sebagai media tanam, alat penunjang kegiatan budidaya stek mawar, gunting stek, penggaris, timbangan analitik, gelas beker, gelas ukur, botol tempat larutan, label, plastik, gelas plastik tempat untuk merendam batang mawar, sprayer, kamera, alat tulis. Bahan yang digunakan batang atau cabang tanaman mawar varietas Rossa Sp., IBA murni (pure analysis of indole 3-butyric acid), akuades, alkohol $96 \%$.

Pembuatan larutan IBA dengan melarutkan sebanyak 25, 50, 75 dan $100 \mathrm{mg}$ hormon IBA murni dalam $10 \mathrm{ml}$ alkohol $96 \%$, kemudian ditambahkan aquades hingga volume menjadi $1000 \mathrm{ml}$. Larutan diaduk hingga homogen kemudian disimpan dalam botol. Tahap selanjutnya adalah penyiapan media tanam dengan mencampur arang sekam, pupuk organik, serta tanah dengan perbandingan (1:1:1). Bahan stek diambil dari batang atau cabang tanaman mawar dengan cara dipotong. Perbedaan umur fisiologi bahan stek diperoleh dengan cara dipotong dari ujung batang atau cabang. Umur bahan stek muda $\left(\mathrm{I}_{1}\right)$ dipotong $10 \mathrm{~cm}$ dari ujung batang atau cabang. Umur bahan stek sedang atau tidak terlalu muda dan tidak terlalu tua $\left(\mathrm{I}_{2}\right)$ dipotong $10 \mathrm{~cm}$ dari $20-40 \mathrm{~cm}$ dari ujung batang atau cabang. serta Umur bahan stek tua dipotong $10 \mathrm{~cm}$ dari 40$50 \mathrm{~cm}$ dari ujung batang atau cabang. Tahap aplikasi IBA pada stek tanaman mawar dengan perendaman masing-masing stek batang atau cabang tanaman mawar dalam larutan IBA sesuai dengan perlakuan yang sudah ditentukan selama dua jam. Bahan stek batang atau cabang tanaman mawar yang sudah direndam ditanam ke dalam polybag yang sudah diisi dengan media tanam. Perawatan stek mawar berupa penyiraman dan aplikasi pestida. Penyiraman dilakukan setiap hari 
yaitu pada pagi hari atau sore hari. Aplikasi pestisida dan fungisida dilakukan pada awal penanaman bahan stek untuk mencegah timbulnya jamur pada batang stek yang ditanam.

\section{HASIL DAN PEMBAHASAN}

Hasil pengamatan jumlah stek hidup dan jumlah tunas terhadap perlakuan umur fisiologi bahan stek dan pemberian berbagai dosis IBA disajikan pada Tabel 1. Berdasarkan data pada tabel tersebut menunjukan bahwa umur bahan stek muda tidak ada yang hidup, baik diperlakukan IBA mau pun tidak. Umur bahan stek sedang menghasilkan stek hidup $100 \%$, dan pemberian IBA tidak meningkatkan jumlah stek hidup tetapi meningkatkan jumlah tunas. Peningkatan pemberian IBA sampai konsentrasi 50 ppm meningkatkan jumlah tunas. Peningkatan konsentrasi IBA menjadi 75 ppm tidak lagi meningkatkan jumlah tunas, bahkan peningkatan IBA menjadi 100 ppm menurunkan jumlah tunas. Umur bahan stek tua menghasilkan jumlah stek hidup sebesar $100 \%$, baik disertai pemberian IBA mau pun tidak. Peningkatan pemberian IBA sampai konsentrasi 100 ppm meningkatkan jumlah tunas. Umur bahan stek muda mengalami kematian 100 $\%$, sehingga tidak mengalami pertumbuhan dan perkembangan tanaman seperti tunas, daun maupun akar. Kematian pada umur bahan stek muda disebabkan oleh terlalu mudanya bahan stek yang diambil yaitu pucuk tanaman. Pengambilan bahan stek yang terlalu muda rentan terhadap kematian sebab mengandung nitrogen yang tinggi serta karbohidrat yang rendah. Menurut Siregar dan Djam'an (2017) menyatakan bahwa stek yang berasal dari bahan stek yang berwarna hijau muda mengandung kadar karbohidrat rendah dan nitrogen tinggi yang dapat mengakibatkan stek menjadi busuk.

Tabel 1. Jumlah Stek Hidup dan Jumlah Tunas

\begin{tabular}{cccccccc}
\hline Parameter & Perlakuan & V0 & V1 & V2 & V3 & V4 & Rata - Rata \\
\hline Jumlah stek & I1 & 0 & 0 & 0 & 0 & 0 & 0 \\
hidup (\%) & $\mathbf{I}$ & 100 & 100 & 100 & 100 & 100 & 100 \\
& $\mathbf{I 3}$ & 100 & 100 & 100 & 100 & 100 & 100 \\
Jumlah & $\mathbf{I}$ & $0,00^{\mathrm{d}}$ & $0,00^{\mathrm{d}}$ & $0,00^{\mathrm{d}}$ & $0,00^{\mathrm{d}}$ & $0,00^{\mathrm{d}}$ & $0,00^{\mathrm{b}}$ \\
tunas & $\mathbf{I}$ & $1,00^{\mathrm{c}}$ & $1,33^{\mathrm{bc}}$ & $2,33^{\mathrm{a}}$ & $3,00^{\mathrm{a}}$ & $1,00^{\mathrm{c}}$ & $1,28^{\mathrm{a}}$ \\
& $\mathbf{I 3}$ & $1,00^{\mathrm{c}}$ & $1,00^{\mathrm{c}}$ & $1,67^{\mathrm{b}}$ & $1,67^{\mathrm{b}}$ & $3,00^{\mathrm{a}}$ & $1,26^{\mathrm{a}}$ \\
\hline & Rata-rata jumlah tunas & $0,67 \mathrm{~b}$ & $0,71^{\mathrm{b}}$ & $0,93^{\mathrm{a}}$ & $1,00^{\mathrm{a}}$ & $0,91^{\mathrm{a}}$ & \\
\hline
\end{tabular}

- Superskrip yang berbeda pada kolom atau baris yang sama menunjukkan perbedaan yang nyata $(\mathrm{p}<0,05)$

- Superskrip yang berbeda pada kolom interaksi menunjukkan perbedan yang nyata $(\mathrm{P}<0,05)$

Umur bahan stek sedang dengan pemberian IBA konsentrasi 50 dan 75 ppm menghasilkan sebanyak 2,33 dan 3 tunas/stek, berbeda nyata dengan pemberian konsentrasi IBA 0, 25 dan 100 ppm masing-masing sebayak 1, 1,33 dan 1 tunas/stek. Umur bahan stek tua dengan pemberian IBA 100 ppm menghasilkan 3 tunas/stek, hal itu sangat berbeda nyata dengan pemberian konsentrasi $0,25,50$ dan 75 ppm yang masing-masing menghasilkan 1, 1, 1,67 dah 1,67 tunas/stek. Pemberian IBA sebanyak 0 ppm dan 25 ppm pada batang tua tidak berbeda nyata, sedangkan pemberian konsentrasi IBA 50 ppm dan 75 ppm tidak berbeda, namun berbeda dengan pemberian IBA 0 dan $25 \mathrm{ppm}$. Umur bahan stek sangat berpengaruh terhadap pertumbuhan stek. Stek yang berasal dari bahan yang tidak terlalu muda dan tidak terlalu tua atau umur sedang memiliki tingkat keberhasilan tumbuh lebih baik dibandingkan dengan yang berasal dari bahan stek umur muda maupun tua. Umur bahan stek mempengaruhi keberhasilan tumbuh tanaman. Menurut Panjaitan et al., (2014) kondisi fisiologis tanaman yang mempengaruhi tingkat keberhasilan stek adalah umur bahan stek, jenis tanaman, adanya tunas dan daun muda pada stek, persediaan bahan makanan, dan zat pengatur tumbuh. Penggunaan bahan stek umur semakin tua maka semakin sulit stek untuk tumbuh tunas hal tersebut terkait dengan keberadaan jaringan sklerensim dan tingkat 
kekerasan jaringan batang atau cabang. Pemberian zat pengatur tumbuh dapat mempengaruhi pertumbuhan stek. Pemberian IBA dari luar dapat mendorong pembelahan sel dan menyebabkan tunas muncul lebih awal. Menurut penelitian Putri et al., (2014) untuk mempercepat proses differensiasi tunas pada stek sangat diperlukan hormon IBA karena keberadaannya sangat menentukan pembentukan dan pertumbuhan tunas tersebut.

Hasil pengamatan panjang tunas terhadap perlakuan umur fisiologi bahan stek dan pemberian berbagai dosis IBA disajikan pada Tabel 2. Umur bahan stek muda, baik diberikan IBA maupun tiak mengalami kematian, tidak ada yang hidup (Tabel 1), sehingga tidak terdapat tunas yang tumbuh. Umur bahan stek sedang dengan pemberian IBA 75 ppm menghasilkan panjang tunas sebesar 26,00 $\mathrm{cm}$, berbeda nyata terhadap umur stek sedang dengan pemberian IBA konsentrasi 0, 25 dan 100 ppm yang menghasilkan panjang tunas masingmasing sebesar 8,67, 10,67 cm dan 9,00 cm. Namun hal itu tidak berbeda nyata terhadap pemberian IBA konsentrasi $50 \mathrm{ppm}$ yang menghasilkan panjang tunas sebesr 20,67 cm. Pemberian IBA dengan konsentrasi 50 ppm pada umur bahan stek sedang menunjukan respon perpanjangan tunas paling baik dibanding dengan pemberian konsentrasi lainnya. Umur bahan stek tua dengan pemberian IBA 100 ppm menghasilkan panjang tunas sebesar $22,00 \mathrm{~cm}$, hal itu sangat berbeda nyata dengan pemberian IBA konsentrasi lainnya, yaitu 0,25 dan $75 \mathrm{ppm}$ yang menghasilkan panjang tunas masing-masing sebesar 6,33, 833 dan 11,67 cm. Pemilihan umur bahan stek sangat mempengaruhi keberhasilan tumbuh tanaman. Semakin tua umur bahan stek yang digunakan maka semakin sulit pula stek untuk tumbuh hal tersebut terkait dengan keberadaan jaringan sklerensim dan tingkat kekerasan jaringan batang atau cabang sertabahan-bahan yang terkandung didalamnya seperti kandungan karbohidrat dan nitrogen. Umur bahan stek sedang memiliki kandungan karbohidrat serta nitrogen yang seimbang sehingga stek mudah untuk tumbuh. Pertumbuhan stek dapat dipacu dengan pemberian hormon IBA. Penggunaan hormon IBA dinilai sangat efektif untuk memacu pertumbuhan stek karena memiliki banyak kelebihan salah satunya adalah akan tetap berada pada tempatnya sehingga tidak menghambat pertumbuhan dan perkembangan tunas.Menurut Shofiana et al., (2013) hormon IBA digunakan karena perbanyakan stek mempunyai beberapa kendala, yaitu zat tumbuh tidak tersebar merata sehingga pertumbuhan stek tidak seragam. IBA memiliki kandungan kimia yang lebih stabil dan daya kerjanya lebih lama sehingga dapat memacu pembentukan akar. IBA yang diberikan pada stek akan tetap berada pada tempat pemberiannya sehingga tidak menghambat pertumbuhan dan perkembangan tunas.

Tabel 2. Panjang Tunas (cm)

\begin{tabular}{ccccccc}
\hline Perlakuan & V0 & V1 & V2 & V3 & V4 & Rata - Rata \\
\hline $\mathbf{I 1}$ & $0,00^{\mathrm{e}}$ & $0,00^{\mathrm{e}}$ & $0,00^{\mathrm{e}}$ & $0,00^{\mathrm{e}}$ & $0,00^{\mathrm{e}}$ & $0,00^{\mathrm{b}}$ \\
$\mathbf{I 2}$ & $8,67^{\mathrm{cd}}$ & $10,67^{\mathrm{c}}$ & $20,67^{\mathrm{ab}}$ & $26,00^{\mathrm{a}}$ & $9,00^{\mathrm{cd}}$ & $15,00^{\mathrm{a}}$ \\
$\mathbf{I 3}$ & $6,33^{\mathrm{d}}$ & $8,33^{\mathrm{cd}}$ & $11,67^{\mathrm{c}}$ & $16,67^{\mathrm{b}}$ & $22,00^{\mathrm{a}}$ & $13,00^{\mathrm{a}}$ \\
\hline Rata-rata jumlah tunas & $5,00^{\mathrm{c}}$ & $6,33^{\mathrm{c}}$ & $10,78^{\mathrm{b}}$ & $14,22^{\mathrm{a}}$ & $10,33^{\mathrm{b}}$ & \\
\hline
\end{tabular}

- Superskrip yang berbeda pada kolom atau baris yang sama menunjukkan perbedaan yang nyata $(\mathrm{p}<0,05)$

- Superskrip yang berbeda pada kolom interaksi menunjukkan perbedan yang nyata $(\mathrm{P}<0,05)$

Hasil pengamatan jumlah daun terhadap perlakuan umur fisiologi bahan stek dan pemberian berbagai dosis IBA disajikan pada Tabel 3. Tabel 3. Menunjukan bahwa umur bahan stek sedang dengan pemberian IBA $75 \mathrm{ppm}$ menghasilkan jumlah daun sebanyak 58 helai, hal tersebut sangat berbeda nyata terhadap pemberian konsentrasi lainnya, yaitu konsentrasi 0, 25, 50 dan 100 ppm mengasilkan jumlah daun masing-masing sebanyak 11, 19,33, 28,33 dan 11,33 helai. Umur bahan stek tua dengan pemberian konsentrasi IBA sebanyak 100 ppm menghasilkan jumlah daun sebanyak 46 helai daun, hal itu sangat berbeda nyata terhadap pemberian konsentrasi IBA sebesar 0, 25, 50 dan 75 ppm. Pemberian konsentrasi IBA 0 ppm, 25 ppm, 50 ppm terhadap umur bahan stek 
tua tidak berbeda nyata yang masing-masing menghasilkan jumlah daun sebanyak 14,00, 14,67 dan 9,00 helai daun. Pemberian konsentrasi IBA 75 ppm dan 100 ppm pada umur bahan stek tua berbeda nyata yaitu masing-masing menghasilkan jumlah daun sebanyak 24,00 dan 46,00 helai daun. Stek yang berasal dari umur bahan tidak terlalu muda dan tidak terlalu tua atau dapat dikategorikan sebagai umur bahan stek sedang paling cepat mengalami pertumbuhan dibanding yang berasal dari umur bahan stek muda maupun umur bahan stek tua. Hal ini sesuai dengan penelitian Firmansyah et al., (2014) bahwa tingkat keberhasilan tanaman yang berasal dari stek sangat dipengaruhi oleh umur bahan stek (eksplan), waktu pengambilan, dan kondisi lingkungan dari bahan stek. Pemberian hormon auksin pada stek batang sangat mempengaruhi pertumbuhan pada tanaman. Salah satu hormon auksin yang baik untuk pertumbuhan stek pada tanaman adalah indole butyric acid (IBA). Semakin tua umur bahan stek yang dipergunakan maka semakin tinggi konsentrasi IBA yang diperlukan untuk memacu pertumbuhan pada tanaman. Menurut penelitian Lusiana et al., (2012) menyatakan bahwa pemberian IBA berpengaruh nyata terhadap jumlah daun tanaman sirih merah. Cepatnya muncul tunas pada stek maka proses pertumbuhan pada stek akan lebih cepat pula sehingga pertambahan jumlah daun yang dihasilkan akan lebih banyak.

Tabel 3. Jumlah Daun

\begin{tabular}{ccccccc}
\hline Perlakuan & V0 & V1 & V2 & V3 & V4 & Rata - Rata \\
\hline I1 & $0,00^{\mathrm{e}}$ & $0,00^{\mathrm{e}}$ & $0,00^{\mathrm{e}}$ & $0,00^{\mathrm{e}}$ & $0,00^{\mathrm{e}}$ & $0,00^{\mathrm{b}}$ \\
$\mathbf{I 2}$ & $11,00^{\mathrm{cd}}$ & $19,33^{\mathrm{bc}}$ & $28,33^{\mathrm{b}}$ & $58,00^{\mathrm{a}}$ & $11,33^{\mathrm{cd}}$ & $25,60^{\mathrm{a}}$ \\
$\mathbf{I 3}$ & $14,00^{\mathrm{cd}}$ & $14,67^{\mathrm{cd}}$ & $9,00^{\mathrm{d}}$ & $24,00^{\mathrm{b}}$ & $46,00^{\mathrm{a}}$ & $21,53^{\mathrm{a}}$ \\
\hline Rata-rata jumlah daun & $8,33^{\mathrm{c}}$ & $11,33^{\mathrm{c}}$ & $12,44^{\mathrm{c}}$ & $27,33^{\mathrm{b}}$ & $19,11^{\mathrm{a}}$ & \\
\hline
\end{tabular}

- Superskrip yang berbeda pada kolom atau baris yang sama menunjukkan perbedaan yang nyata $(\mathrm{p}<0,05)$

- Superskrip yang berbeda pada kolom interaksi menunjukkan perbedan yang nyata $(\mathrm{P}<0,05)$

Tabel 4. Panjang Akar (cm) pada Umur Bahan Stek dan Konsentrasi IBA yang Berbeda.

\begin{tabular}{ccccccc}
\hline Perlakuan & V0 & V1 & V2 & V3 & V4 & Rata - Rata \\
\hline I1 & $0,00^{\mathrm{g}}$ & $0,00^{\mathrm{g}}$ & $0,00^{\mathrm{g}}$ & $0,00^{\mathrm{g}}$ & $0,00^{\mathrm{g}}$ & $0,00^{\mathrm{b}}$ \\
$\mathbf{I} 2$ & $7,67^{\mathrm{f}}$ & $11,00^{\mathrm{de}}$ & $15,00^{\mathrm{c}}$ & $24,00^{\mathrm{a}}$ & $8,33^{\text {ef }}$ & $13,20^{\mathrm{a}}$ \\
$\mathbf{I 3}$ & $6,67^{\mathrm{f}}$ & $11,67^{\mathrm{d}}$ & $13,00^{\mathrm{cd}}$ & $18,00^{\mathrm{b}}$ & $18,67^{\mathrm{b}}$ & $13,60^{\mathrm{a}}$ \\
\hline Rata-rata panjang akar & $4,78^{\mathrm{c}}$ & $7,56^{\mathrm{b}}$ & $9,33^{\mathrm{b}}$ & $14,00^{\mathrm{a}}$ & $9,00^{\mathrm{b}}$ & \\
\hline
\end{tabular}

- Superskrip yang berbeda pada kolom atau baris yang sama menunjukkan perbedaan yang nyata $(\mathrm{p}<0,05)$

- Superskrip yang berbeda pada kolom interaksi menunjukkan perbedan yang nyata $(\mathrm{P}<0,05)$

Hasil pengamatan jumlah daun terhadap perlakuan umur fisiologi bahan stek dan pemberian berbagai dosis IBA disajikan pada Tabel 4 . Tabel 4. menunjukan bahwa umur bahan stek muda yang diberikan IBA maupun tidak mengalani kematian, tidak ada yang hidup sehingga tidak terdapat jumlah tunas yang tumbuh (Tabel 1) dan panjang tunas (Tabel 2) dan jumlah daun (Tabel 3) yang diberikan dengan konsentrasi IBA 0, 25, 50, 75 dan 100 ppm tidak berpengaruh nyata terhadap pertumbuhan panjang akar pada stek tanaman mawar sebab stek mengalami kematian. Umur bahan stek sedang dengan pemberian IBA 75 ppm memperlihatkan pertumbuhan akar yang paling panjang yaitu sebesar $24,00 \mathrm{~cm}$ dan berbeda nyata dengan pemberian IBA konsentrasi $0,25,50$ dan $100 \mathrm{ppm}$, masing-masing menghasilkan panjang akar sebesar 7,67 cm, 11,00 cm, 15,00 cm serta 8,33 $\mathrm{cm}$. Umur bahan stek tua, pemberian IBA konsentrasi 25 dan 50 ppm meningkatkan panjang akar dibanding kontrol, masing-masing 11,67 dan $13,00 \mathrm{~cm}$ dibanding $6,67 \mathrm{~cm}$. Pemberian IBA dengan konsentrasi 75 dan 100 ppm tidak berbeda nyata yaitu masing-masing menghasilkan panjang akar sebesar 18,00 dan 18,67 cm, tetapi berbeda dengan pemberian IBA 0,25 dan $50 \mathrm{ppm}$ 
Pertumbuhan akar pada stek tanaman dipengaruhi oleh umur bahanstek yang digunakan. Stek paling baik adalah stek yang berasal dari umur bahan stek sedang, sebab pada umur bahan sedang terdapat nutrisi-nutrisi yang dapat membantu percepatan tumbuh tanaman. Umur bahan stek tua mengalami kesulitan untuk berakar dikarenakan pada umur bahan stek tua mengalami penurunan nutrisi yang berfungsi untuk membantu pertumbuhan akar pada stek serta telah terbentuknya jaringan sklerensim dan tingkat kekerasan jaringan batang atau cabang. Menurut Hidayat (2010) penurunan kemampuan berakar pada jaringan tanaman tua kemungkinan karena berkurangnya kandungan senyawa fenol yang berfungsi sebagai kofaktor IBA. Selain itu pada bahan stek tua telah terbentuk jaringan sklerenkimyang sering menghambat inisiasi akar. Supriyanto dan Prakasa (2011) berpendapat bahwa keberhasilan stek dalam membentuk akar dipengaruhi oleh umur bahan tanam, fase pertumbuhan dan perbedaan bagian tanaman yang digunakan sebagai bahan stek. Umur bahan stek yang digunakan tersebut berkaitan dengan kandungan nutrisi didalamnya terutama karbohidrat, protein, lipid, nitrogen, enzim, hormon dan rooting cofactor. Selain sumber bahan stek keberhasilan stek membentuk akar juga dipengaruhi oleh hormon yang terkandung didalamnya yaitu hormon IBA. Fungsi utama hormon IBA adalah untuk merangsang pertumbuhan akar pada tanaman. Hal ini sesuai dengan pendapat Wulandariet al., (2010) yang menyatakan bahwa IBA adalah salah satu hormone pertumbuhan yang mempunyai pengaruh paling besar pada pertumbuhan akar. Pemberian zat pengatur tumbuh akan memberikan respon fisiologis pertumbuhan dan perkembangan tanaman.

\section{KESIMPULAN}

Berdasarkan penelitian yang telah dilakukan dapat disimpulkan bahwa bagian ujung batang atau cabang tanaman berumur muda tidak dapat digunakan sebagai bahan stek. Besarnya konsentrasi IBA yang harus diberikan untuk meningkatkan peluang hidup dan mempercepat pembentukan akar dan tunas stek tanaman bunga mawar tergantung umur bahan stek. Umur bahan stek sedang diperlukan konsentrasi IBA 50 ppm dan umur bahan stek tua diperlukan konsentrasi $75 \mathrm{ppm}$. Umur bahan stek sedang, tidak terlalu tua dan tidak terlalu muda terletak pada daerah perubahan warna hijau ke coklat pada batang atau cabang yang akan digunakan stek. Semakin tua umur bahan stek yang digunakan maka semakin besar pula konsentrasi IBA yang diperlukan untuk memacu pertumbuhan pada stek tanaman mawar.

\section{DAFTAR PUSTAKA}

Adriana, W. Widaryanti, D. Prehaten dan G. Nawangsih. 2014. Pertumbuhan stek cabang bambu petung (Dendrocalamus asper) pada media tanah, arang sekam dan kombinasinya. J. Ilmu Kehutanan, 8 (1) : 34-41

Firmansyah, S. F., Rochmatino, Kamsiah. 2014. Pengaruh pemberian iba dan komposisi media terhadap pertumbuhan stek Sansevieria cylindrica var. Patula . J. Biologi, 1 (2) : 161 - 165

Fitriani S., D. Astiani, Wahdina. 2017. Perbanyakan tanaman pasak bumi (Eurycoma longifolia jack) secara generatif dan vegetatf di persemaian. J. Hutan Lestari, 5 (1) : 113 120

Hidayat. 2010. Growth of primary, secondary and tertiary roots of seedling-stem cuttings of toona sinensis roem. $\mathrm{j}$. forestry reaseach, 10 (2) : 1-8

Lusiana, Riza Linda, dan Mukarlina. 2012. Respon pertumbuhan stek batang sirih merah (Piper crocatum Ruiz dan Pav) setelah direndam dalam urine sapi. J. protobiont, 2 (3) : 157 160 .

Mattjik, N. A. 2009. Budidaya bunga potong dan tanaman hias. departemen agronomi dan hortikultura, fakultas pertanian, institut pertanian bogor. 103-117 
Panjaitan, L. R. H., J. Ginting, Haryati. 2014. Respons pertumbuhan berbagai ukuran diameter batang stek bugenvil (bougainvillea spectabilis willd.) terhadap pemberian zat pengatur tumbuh. J. online agroekoteknologi, 2 (4) : 1384 - 1390

Putri KP, Danu dan Bustomi S. 2014. Pengaruh zat pengatur tumbuh IBA terhadap keberhasilan stek pucuk kaliandra (Calliandra calothyrsus Meisner). J. Perbenihan tanaman hutan, 2 (1) : 49-58.

Sari, F.O., Rugayah dan Y. C. Ginting. 2014. Pengaruh konsentrasi iba (indole butyric acid) dan jenis media tanam terhadap pertumbuhan bibit nanas (ananas comosus [l.] merr) asal tunas mahkota. J. Agrotek Tropika. 2 (1) : 43-48

Shofiana A., Y. S. Rahayu dan L. S. Budipramana. 2013. Pengaruh pemberian berbagai konsentrasi hormon iba (indole butyric acid) terhadap pertumbuhan akar pada stek batang tanaman buah naga (hylocereus undatus). $J$. LemteraBio, 2 (1) : 101-105

Siregar, N. Dan Djam'an, D.F. 2017. Pengaruh bahan tanaman terhadap keberhasilan setek kranji (Pongamia pinnata). Prossemnas Masy Biodiv, 3 (1) : 23-27

Supriyanto, dan K.E. Prakasa. 2011. Pengaruh zat pengatur tumbuh rootone-f terhadap pertumbuhan stek dua banga (Mollucana blume.) J. Silvikultur Tropika, 3 (1) : 59-65

Suradinata Y.R., dan A. Wulansari. 2015. Respon tanaman mawar batik (Rosa hybrida L.) dengan penggunaan konsentrasi 1methylcyclopropene (1-MCP) pada beberapa tingkat kemekaran bunga. J. Kultivasi, 14 (2) : 55-62

Wulandari, RC, L. Riza Linda, dan Mukarlina 2013. Pertumbuhan setek melati putih (Jasminum sambac (L) W. Ait.) dengan pemberian air kelapa dan IBA (indole butyric acid). J. Protobiont., 2 (2) : 39-43. 